\title{
EVOLUSI BINTANG PADA PEMBENTUKAN TATA SURYA DAN SISTEM KEPLANETAN
}

\author{
Khilyatul Khoiriyah \\ Madrasah Aliyyah NU Demak; e_mail: khiliyah@gmail.com
}

Diterima: 29 September 2016. Disetujui: 12 Oktober 2016. Dipublikasikan: Oktober 2016

\begin{abstract}
This research is the literature studies that provide an introduction to the theory of the formation and early evolution of solar system and planetary systems. Theories that discussed are limit on the theory which has been closed to the truth of observation result. Topics include the structure of solar system, star formation, the structure of evolution and dispersal of protoplanetary disks, planetesimals formation, terrestrial and giant planets formation, the formation of the smaller objects in the solar system and planet migration.
\end{abstract}

\begin{abstract}
Abstrak: Penelitian ini merupakan studi literatur yang membahas tentang masalah pembentukan dan evolusi awal tata surya dan sistem keplanetan dengan memberikan konsep dasar yang ringkas. Teori-teori yang dikaji secara khusus dibatasi pada teori yang telah mendekati kebenaran dari hasil pengamatan. Topik yang dibahas adalah struktur tata surya, pembentukan bintang, struktur evolusi dan pembubaran cakram protoplanet, pembentukan planetesimal, planet terestrial dan planet raksasa, pembentukan benda-benda kecil dalam tata surya dan migrasi planet.
\end{abstract}

(C) 2016 Pendidikan Fisika, FTK IAIN Raden Intan Lampung

Kata kunci: cakram protoplanet pembentukan bintang, planet, migrasi planet, tata surya.

\section{PENDAHULUAN}

Studi teoritis tentang pembentukan tata surya dan sistem keplanetan telah berlangsung lama. Perkembangan teori yang telah ada, secara garis besar dapat dibedakan berdasarkan jamannya menjadi tiga kelompok.

Jaman pertama adalah teori pembentukan tata surya sebelum tahun 1960. Teori yang telah berkembang pada jaman ini di antaranya adalah: teori komet Buffon, teori nebula Laplace, model Roche, teori planetesimal ChamberlinMoulton, teori pasang-surut Jeans, teori pertumbuhan Schmidt-Lyttleton dan teori pusaran von Weizsäcker.

Jaman kedua adalah teori-teori pembentukan tata surya antara tahun 1960 sampai tahun 1970. Teori-teori tersebut di antaranya adalah: teori protoplanet $\mathrm{Mc}$ Crea, teori penangkapan Woolfson, dan teori Nebula Matahari. Tentu saja teoriteori tersebut masih belum dapat dianggap benar karena masing-masing mempunyai kelebihan dan kekurangan. Tidaklah mudah untuk menemukan teori yang benar. Hasil teoritis diharapkan akan dapat mendekati hasil pengamatan.

Jaman ketiga adalah teori pembentukan tata surya setelah tahun 1970. Pada jaman ini hanya ada satu teori yaitu teori Laplace modern.

Selain pembagian atas tiga kategori jaman di atas, terdapat dua mazhab utama yang mencoba menjelaskan tentang asal mula tata surya kita. Mazhab pertama adalah mazhab monoistik. Matahari dan planet serta anasir yang ada di dalamnya berasal dari materi yang sama. Pencetus hipotesis ini adalah Laplace dan beberapa filosof sebelumnya seperti Descartes, Immanuel Kant, dan von Weizsäcker.

Mazhab yang kedua adalah mazhab dualistik yang dianut oleh Buffon, Chamberlain, Moulton, Jeans, Jeffrey, Woolfson, Schmidt dan Lyttleton. 
Matahari dan planet serta anasir kosmik lainnya yang ada di dalamnya tidak harus berasal dari materi yang sama, serta bisa terbentuk pada kurun waktu yang berbeda. Setiap teori memiliki keberhasilan dalam memecahkan masalah tertentu, namun bisa jadi mempunyai kelemahan untuk kasus yang berbeda.

Beberapa peneliti lain juga telah melakukan riset dalam bidang ini. Safronov (1969) telah banyak menuliskan ide-ide dasar tentang teori pembentukan planet terestrial dalam monograf klasiknya yang berjudul "Evolusi awan protoplanet serta pembentukan bumi dan planetplanet". Mizuno (1980) juga telah mengemukakan unsur penting teori pertambahan inti (akresi) pada pembentukan gas raksasa.

Data terbaru pada dasawarsa terakhir memberikan petunjuk yang menarik dalam masalah ini. Termasuk pengamatan cakram protoplanet, penemuan sabuk Kuiper dan penemuan sistem planet-planet ekstrasolar. Meskipun pengamatan telah menegaskan prakiraan prediksi, tetapi juga telah ditekankan perlunya ekplorasi teori yang baru.

Ada beberapa pertanyaan utama yang selalu muncul dan harus dicari jawabannya mengenai pembentukan sistem keplanetan dan evolusi awalnya. Bagaimana planet-planet raksasa dan terestrial terbentuk? Apakah berasal dari satu benda yang sama? Apakah terbentuk secara bertahap? Apakah susunan tata surya itu unik? Apakah ada tata surya lain selain tata surya kita? Bagaimana planet bisa dihuni? Bagaimana benda-benda kecil luar angkasa terbentuk?

Penelitian ini akan mengkaji secara teoritis tentang masalah pembentukan dan evolusi awal sistem keplanetan dengan memberikan pengenalan konsep dasar secara ringkas. Untuk dapat mengkaji masalah ini dengan baik, pertama kali perlu merangkum ukuran-ukuran dasar yang dapat diamati dari tata surya dan sistem keplanetan.
Ukuran-ukuran dasar tersebut diambil dari hasil pengamatan yang telah dilakukan dalam dasawarsa terakhir ini, baik dalam bentuk data kuantitatif, grafik maupun gambar. Penurunan secara teoritis tersebut kemudian dikembangkan dan dibandingkan dengan hasil pengamatan yang pernah dilakukan dalam riset-riset sebelumnya, untuk menentukan teori yang paling mendekati kebenaran.

\section{METODE PENELITIAN}

Penelitian ini menggunakan metode studi literatur. Sehingga, dengan menggunakan metode ini, penelitian dilakukan dengan cara mengumpulkan dan mengkaji secara teoritis buku-buku referensi beserta artikel-artikel ilmiah yang relevan dengan masalah pembentukan dan evolusi awal sistem keplanetan.

Pada umumnya beberapa buku atau artikel ilmiah menggunakan simbol yang berbeda. Oleh karena itu, dalam penulisan laporan penelitian ini akan dilakukan penyeragaman dan penyelarasan dalam penulisan simbol agar tidak terjadi kesalahan pemahaman.

Selain itu juga dilakukan pengumpulan data-data kuantitatif bendabenda luar angkasa yang telah tersedia. Data-data tersebut dapat berupa tabel, gambar, grafik dan lain sebagainya. Hal ini dilakukan untuk mendukung perhitungan teoritis kuantitatif besaran-besaran yang terkait di dalamnya.

\section{HASIL DAN PEMBAHASAN}

Schilling, G. (1999) mengatakan tata surya terbentuk dari sebuah cakram. Saat bintang menjadi cukup panas, pertumbuhan material akan berhenti dan menerbangkan cakram. Hal ini terjadi setelah planet-planet terbentuk di sekeliling bintang. Sehingga orbit planetplanet merupakan sisa kerangka cakram tersebut. Hal ini juga dapat menjelaskan sebab-sebab semua planet mengelilingi 
matahari dalam arah yang sama dan kirakira berada dalam bidang yang sama.

Kenyon, S. J. (2000) meninjau kembali teori tentang runtuhnya cakram protostellar. Diawali dengan pendahuluan singkat tentang pertumbuhan cakram fisis, Kenyon mengambarkan model koagulasi pembentukan planet pada daerah terluar dari cakram planetesimal. Model koagulasi sabuk Kuiper menghasilkan objek seukuran Pluto dalam skala waktu 10 - 40 Myr. Model ini menghasilkan distribusi ukuran yang sesuai dengan observasi objek sabuk Kuiper dengan magnitudo merah, $\mathrm{R}$ $\approx 20-27$.

Cassen, P. (2006) memberikan gagasan bahwa planet pada sistem solar terbentuk dari cakram protoplanet. Material berputar-putar di sekitar matahari dan secara alamiah mengikutinya. Keberadaan cakram progenitor secara implisit merupakan gagasan Descartes dan telah menjadi ciri-ciri umum untuk menjelaskan aspek-aspek sistematis tata surya.

Akibat teori Nebular ini, sistem keplanetan merupakan konsekuensi luar biasa dari pembentukan bintang. keplanetan merupakan konsekuensi luar biasa dari pembentukan bintang. Astronomi moderen telah memenuhi aspek-aspek esensial dari hipotesis ini dengan membuka keberadaan planet di sekitar bintang dan cakram-cakram di sekitar bintang-bintang muda. Gagasan bahwa planet terbentuk dari cakram yang melingkungi bintang membawa akibat bahwa bagaimanapun juga bahan pembentuk sistem keplanetan berhubungan dengan cakram asal mereka.

Alles, D. L. (2006) mengkaji tentang pembentukan bintang-bintang dan tata surya. Sistem protoplanet merupakan sistem yang sangat kompleks. Alles juga melampirkan gambar-gambar terbentuknya bintang berdasarkan dari hasil pengamatan.

Bintang terbentuk setelah ada peristiwa keruntuhan gravitasi dari sebuah awan Hidrogen interstellar. Cakram debu terbentuk mengelilingi bintang yang baru lahir. Jika ada material yang jatuh di atas bintang, sebagian akan menjadi panas dan dikeluarkan sepanjang sumbu putar bintang. Cakram akan terlihat melebar dengan bagian tengah yang lebih tipis di bandingkan dengan bagian tepinya.

Armitage, P. J. (2007) menjelaskan teori pembentukan sistem keplanetan dan evolusi awalnya. Masalah-masalah yang dikaji meliputi: (i) struktur, evolusi dan bubarnya cakram protoplanet, (ii) pembentukan planetesimal, planet-planet terestrial dan raksasa, (iii) evolusi orbital karena migrasi cakram gas, (iv) hamburan planetesimal, dan (v) interaksi planetplanet. Armitage mengusulkan model teoritis yang sekarang didukung oleh pengamatan tata surya dan sistem planet luar Matahari.

Sedikitnya ada tiga mekanisme yang dapat menimbulkan evolusi pembentukan orbital substansial, yaitu:

1. Interaksi antara planet-planet dengan cakram protoplanet gas Menurut Goldreich dan Tremaine (1980), interaksi antar planet dengan cakram protoplanet gas akan menyebabkan migrasi orbital sebagai konsekuensi perubahan momentum sudut antara planet dengan cakram gas. Cakram gas yang masih ada dapat menjadi penting untuk massa planet terestrial dan raksasa. Menurut Lin, Bodenheimer dan Richardson (1996), migrasi cakram gas memberikan penjelasan teoritis baku pada keberadaan Jupiter yang panas.

2. Interaksi antara planet-planet dan sebuah cakram planetesimal sisa. Menurut Levinson, dkk (2007), planet (khususnya planet raksasa) juga dapat merubah momentum sudutnya karena adanya interaksi dengan lemparan planetesimal yang keluar dari proses pembentukan planet. Mekanisme ini menyebabkan migrasi orbital dari sebagian kecil raksasa es dan mungkin 
juga pada Saturnus selama sejarah awal tata surya.

3. Interaksi dalam sistem awal yang tidak stabil dari dua atau lebih planet-planet bermassa besar. Menurut Lin dan Ida (1997), Rasio dan Ford (1996), Weidenchilling dan Marzari (1996), tidak ada jaminan sistem planet yang terbentuk akan menjadi stabil selamanya. Ketidakstabilan dapat menyebabkan hamburan planet-planet, yang biasanya menghasilkan pelemparan planet yang bermassa lebih rendah, meninggalkan survivor pada orbit eksentrik. Hal ini mungkin akan dapat menjadi dasar asal mula orbit eksentrik yang terlihat pada sistem planet luar Matahari.

Sebuah teori pembentukan tata surya dan sistem keplanetan harus dapat menjelaskan data-data dan fakta-fakta hasil pengamatan. Sebelum banyak ditemukan beberapa fakta tentang tata surya dan sistem keplanetan, Laplace telah mengemukakan gagasan tentang asal mula pembentukan tata surya dan sistem keplanetan. Menurut Laplace, ada empat fakta yang harus dijelaskan pada teori pembentukan tata surya, yaitu :

1. Orbit semua planet-planet boleh dikatakan (karena inklinasi yang kecil) berada pada satu bidang yang sama.

2. Semua planet mengelilingi Matahari dalam arah yang sama.

3. Lintasan orbit planet hampir semuanya berupa lingkaran.

4. Putaran planet pada sumbunya sama dengan arah orbitnya pada Matahari.

Meskipun terdapat gagasan Laplace tersebut yang tidak sesuai dengan fakta yang didapatkan pada masa sekarang, setidaknya Laplace telah memberikan dasar yang dapat digunakan untuk membangun teori asal mula pembentukan tata surya dan sistem keplanetan.

Menurut Laplace, berawal dari suatu putaran awan gas, keempat gagasan tersebut akan terpenuhi. Jika sekumpulan awan gas runtuh karena pengaruh gaya gravitasi, akan terbentuk pusaran yang menghasilkan gaya sentrifugal yang akan menyebabkan keruntuhan di sepanjang sumbu putarnya. Karena terjadi proses keruntuhan awan, energi gravitasi diubah menjadi panas yang membuat tekanan di dalam awan gas naik dan akhirnya keruntuhan berhenti dengan terbentuknya cakram gas panas yang berpusar.

Laplace mengusulkan, Matahari terbentuk di pusat cakram dan planetplanet terbentuk dari material yang keluar dari sekelilingnya. Menurutnya, karena cakram gas menjadi dingin, cakram akan pecah menjadi cincin-cincin. Material dalam cincin-cincin tersebut akan menggumpal secara bertahap membentuk planet. Mekanisme teori ini dapat menjelaskan secara sederhana penyebab planet-planet bergerak mengelilingi Matahari pada arah yang sama dan putaran orbitnya berada pada bidang yang sama, dengan lintasan yang hampir menyerupai lingkaran.

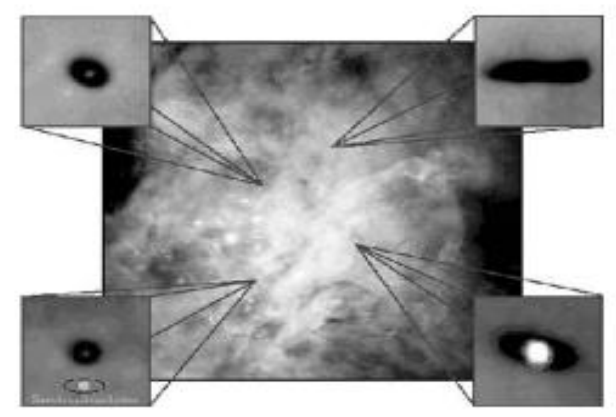

Gambar 1. Nebula Orion

(Sumber: Eales, S. Planet and Planetary Systems, p 134, 2009)

Gagasan Laplace bahwa pembentukan tata surya dan sistem keplanetan berawal dari awan gas telah terbukti pada masa sekarang. Gambar 1. memperlihatkan Nebula Orion yang diambil oleh teleskop luar angkasa Hubble. Nebula Orion merupakan bagian dari awan molekuler Nebula.

Gambar tersebut menarik bagi para astrofisikawan, terutama bagian-bagian 
yang diperlihatkan pada sisipan (inset) Empat diantaranya telah disisipkan pada gambar. Tiga diantaranya terdapat bintang muda yang terletak pada pusat potongan. Potongan-potongan tersebut berupa bayangan hitam pada cakram di sekitar bintang yang tersembunyi di balik cahaya nebula karena adanya partikel-partikel kecil berupa debu di dalam cakram. Pada sisipan di sebelah kanan atas, terlihat bintang tersembunyi di dalam cakram dan debu. Kemungkinan cakram tersebut akan segera dapat diamati secara terperinci pada operasi Atacama Large Millimetre Array yang akan dimulai tahun 2010 karena debu meneruskan sinar infra merah dan radiasi submilimeter.

Pada ruang angkasa di antara bintang-bintang merupakan ruang yang hampir kosong. Pada ruang tersebut terjadi hamburan oleh atom-atom Hidrogen. Atom-atom tersebut berada dalam jarak yang saling berjauhan dan bergerak sangat cepat karena sangat panas akibat terbakar oleh radiasi ultraviolet dari bintang. Keadaan ini membuat atom menjadi sulit untuk membentuk ikatan molekuler.

Beberapa bagian ruang angkasa terdapat daerah perbatasan atom-atom yang tidak terlalu lebar. Sinar kosmik memadatkan awan-awan debu dan gas yang tebal. Ketika awan-awan menjadi lebih dingin dibandingkan dengan tempat lain di sekitarnya, awan-awan akan menjadi tempat yang sempurna untuk pembentukan bintang. Saat kerapatan daerah tersebut mancapai 1000 kali lebih besar dibandingkan daerah lainnya, atomatom akan bergabung membentuk molekul dan awan gas menjadi awan molekuler. Awan molekuler ini bengkak, menggembung, kental dan tidak halus.

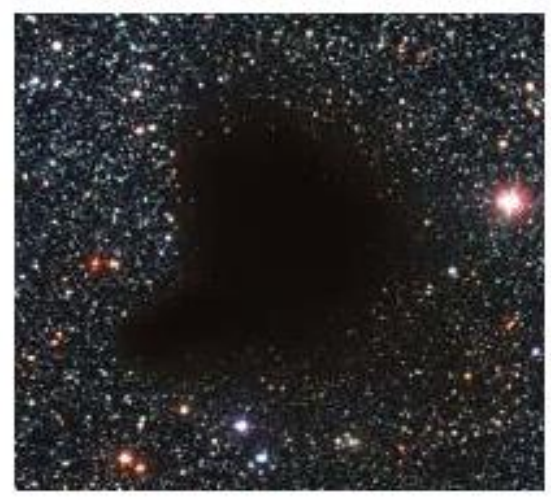

Gambar 2. Awan Molekuler Bamard 68 (Sumber: Pezzaglia, B. Stellar Evolution, 2006)

Gambar 2. adalah gambar awan molekuler Bamard 68 yang merupakan tempat awal dimulainya pembentukan bintang. Pada gambar tersebut terlihat seolah terdapat sebuah daerah "kosong" yang dingin, bersuhu antara $10-30 \mathrm{~K}$, padahal wilayah itu merupakan tempat yang lebih rapat dibandingkan dengan daerah di sekitarnya. Sebagian besar berisi atom-atom Hidrogen dan Helium. Suhu yang dingin dan kerapatan yang relatif tinggi menyebabkan gaya gravitasi lebih dominan dibandingkan dengan tekanan termal sehingga terjadi keruntuhan awan. Selama proses keruntuhan berlangsung, awan berada dalam suhu kurang dari 100 $\mathrm{K}$ dan memancarkan sinar infra merah, sehingga mekanismenya tidak bisa diamati secara terperinci.

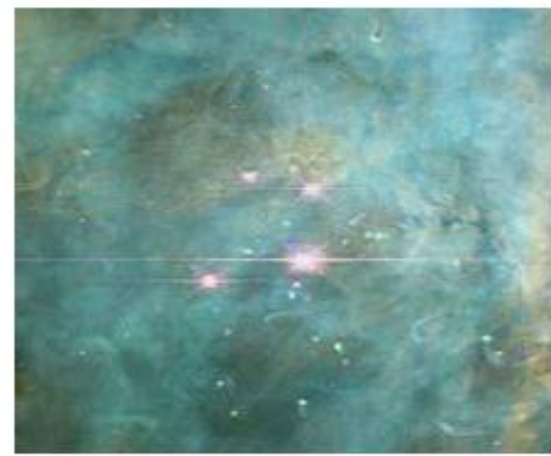

Gambar 3. Keruntuhan Awan Nebula Orion (Sumber: Pezzaglia, B., Stellar Evolution, 2006)

Gambar 3. merupakan gambar keruntuhan awan Nebula Orion. Pada 
gambar tersebut terlihat ada beberapa kilatan cahaya yang diduga sebagai tempat terjadinya keruntuhan awan.

Gambar 4. merupakan gambar simulasi awan molekuler yang mengalami proses turbulensi. Turbulensi yang terjadi merupakan proses perputaran awan yang menyebabkan keruntuhan awan karena gravitasi. Pada gambar terlihat, potongan awan lepas menjadi bagian yang lebih kecil. Potongan tersebut kemudian berpusar sehingga ada bagian yang runtuh. Potongan awan terus berpusar sampai didapatkan satu bagian yang lebih kecil lagi. Keruntuhan akan berhenti karena tekanan naik yang menyebabkan gaya gravitasi diubah menjadi panas. Awan gas menjadi padat. Sehingga ketika kesetimbangan hidrostatik tercapai, awan gas berubah menjadi protobintang.

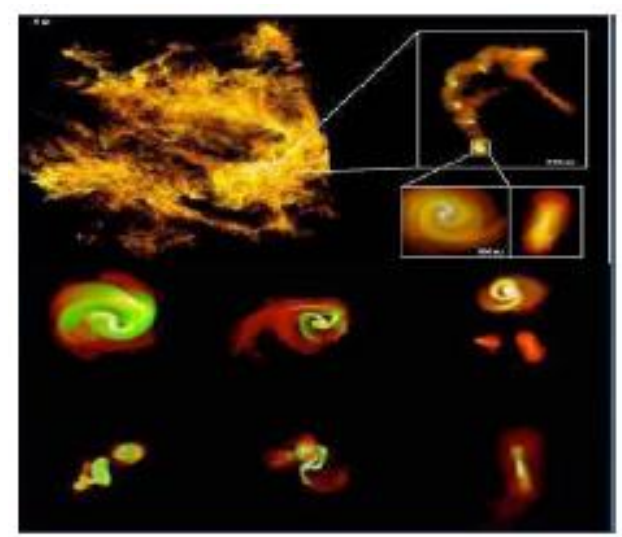

Gambar 4. Simulasi Turbulensi Awan Molekuler

(Courtesy: Padoan, Kritsuk, Norman, diakses 30 Mei 2009)

Protobintang merupakan bintang yang baru terbentuk. Protobintang yang baru saja terbentuk akan menjadi lebih padat dibandingkan dengan kerapatan awan di sekitarnya. Material-material yang bergabung menjadi protobintang memiliki peluang untuk dilempar dan akan berpusar kembali di sekitar. Jika pusaran itu mencapai kemampatan yang sangat tinggi, maka unsur-unsur yang bergabung akan membentuk cakram tipis di sekitar protobintang.

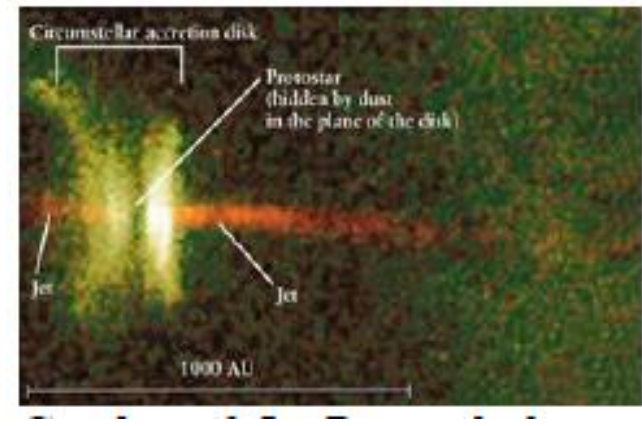

Gambar 5. Pertumbuhan Cakram Protostar (Sumber: Pezzaglia, B., Stellar Evolution, 2006)

Gambar 5. menunjukkan pertumbuhan cakram protobintang. Pada gambar tersebut terlihat adanya pertumbuhan cakram circumstellar di antara protobintang. Protobintang tertutup debu sehingga tidak terlihat. Di tengahtengah cakram tampak adanya emisi yang memancar dalam arah tegak lurus dengan cakram.

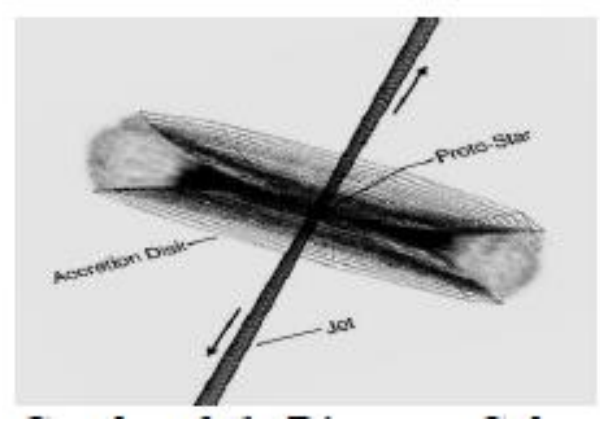

Gambar 6. Diagram Cakram Circumstellar (Courtsey of NASA)

Gambar.6.

menunjukkan mekanisme pembentukan cakram yang mengelilingi bintang. Pancaran yang keluar membawa fraksi material jatuh di sepanjang bintang. Pancaran tersebut seperti aliran air yang menyembur dari pipa air, menubruk pasir, membersihkan lubang di sekitar bintang dan mencegah gas tambahan jatuh di atas cakram circumstellar. Cakram terlihat mengembang di sekitar bintang. Pelebaran cakram pada bagian yang dekat dengan 
bintang terlihat lebih tipis dibandingkan dengan bagian yang lebih jauh dari bintang.

Material pada protobintang yang baru terbentuk akan bertambah dengan cepat. Material tersebut akan bergerak lebih cepat ke permukaan protobintang. Ketika protobintang menyebar, mekanisme pertumbuhannya merupakan mekanisme abrasi sehingga protobintang akan kehilangan massa. Untuk melestarikan momentum sudutnya, di sekitar protobintang harus terbentuk cakram protostellar.

Ketika potongan-potongan awan bergerak lebih cepat daripada saat keruntuhannya, putaran awan menjadi pipih dan membentuk cakram protostellar. Cakram protostellar memperlambat rotasi protobintang. Perlambatan rotasi protobintang membangkitkan medan magnetik. Medan magnetik membangkitkan angin protostellar.

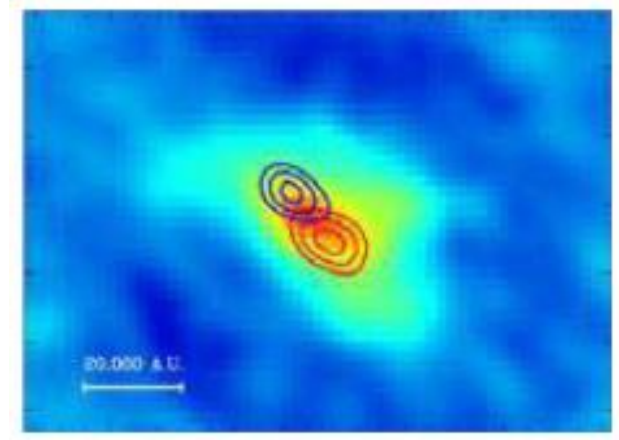

Gambar 7. Pembentukan Cakram Protostellar

(Sumber: Pezzaglia, B. Stellar Evolution, 2006)

Gambar 7. menunjukkan pembentukan cakram protostellar. Pada gambar tersebut memperlihatkan pancaran termal debu cakram protostellar NGC 7538 S pada jarak 10.000 tahun cahaya. Massa cakram gasnya sama dengan 100 kali massa Matahari. Kerapatan inti awannya sama dengan 1000 kali kerapatan Matahari. Warna hijau menunjukkan inti awan. Warna kuning menunjukkan cakram protostellar. Warna merah menunjukkan protostar. Kountur warna merah menunjukkan rotasi cakram yang tertarik ke belakang (mundur). Kountur biru menunjukkan rotasi cakram yang menuju ke arah kita (maju). Cakram protostellar ini diduga sebagai awal terbentuknya sistem keplanetan.

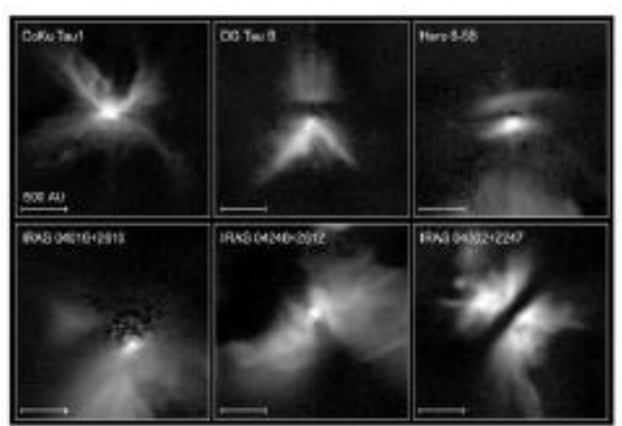

Gambar 8. Pembentukan Cakram Protostellar

(Sumber: Boss, A., From Moleculer Clouds to Circumstellar Disks, p 73, 2004)

Gambar 8. memperlihatkan pembentukan cakram protostellar pada daerah pembentukan bintang Taurus yang diamati dengan teleskop luar angkasa Hubble dan dipotret dengan kamera NICMOS. Pada gambar tersebut, awalnya cakram terlihat berupa konfigurasi bentuk jam pasir dengan aliran molekuler yang terbuka. Bintang pusat tersembunyi, tampak sebagai bayangan hitam dan cakram terbentuk di sisi atas dan bawah. Cahayanya dipantulkan dari permukaan cakram ke arah atas dan bawah oleh wilayah gas dan debu.

Hal ini menyebabkan terbentuknya lingkungan radiasi yang sangat berbeda di antara dua daerah ekstrim tersebut. Taurus menjadi relatif lunak dan Orion menjadi kebanjiran radiasi ultraviolet saat awal terbentuk bintang masif.

Bintang terbentuk karena adanya keruntuhan gravitasi awan interstellar Hidrogen. Saat bintang menjadi cukup panas, pertumbuhan material bintang akan terhenti dan material bintang akan menerbangkan cakram. 


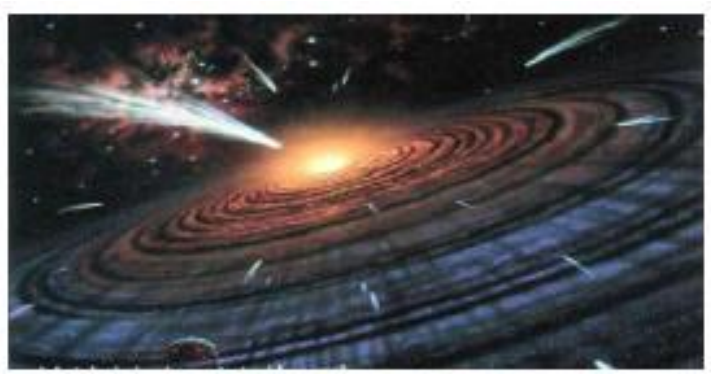

Gambar 9. Cakram debu di sekitar bintang (Sumber: Schilling, G., From a Swirl of Gas, a Plant is Born, Science 286, 1999)

Menurut teori dan hasil pengamatan teleskop luar angkasa Hubble, cakram debu terbentuk di sekitar bintang yang baru lahir. Ilustrasi adanya cakram debu di sekitar bintang yang baru lahir dapat dilihat pada Gambar 9.

Perbedaan fisis yang perlu digambarkan antara cakram circumstellar pasif dengan cakram circumstellar aktif adalah luminositas dan energi potensial gravitasi yang dilepaskan oleh gas yang mengalir di dalamnya. Dengan mengabaikan energi pertumbuhan, laju pertumbuhan kritis cakram dengan laju pertumbuhan $\stackrel{\mathrm{g}}{M}$, luminositas $L_{<}$, dan radius $R^{*}=2 R<$ dapat dinyatakan dengan persamaan

$$
\frac{1}{4} L_{\mathrm{e}}=\frac{G M_{*} \cdot \stackrel{\mathrm{g}}{M}}{2 R_{*}}
$$

Jika cakram yang pipih menangkap $1 / 4$ fluks bintang, maka secara numeric dapat dinyatakan

$$
\stackrel{\mathrm{g}}{M} \approx 3 \times 10^{-8} M_{<} y r^{-1}
$$

Struktur termal cakram pada saat awal didominasi oleh pemanasan internal yang disebabkan oleh pertumbuhan cakram. Pertumbuhan cakram dapat ditinjau dari struktur vertikal cakram circumstellar pasif atau aktif dalam keseimbangan hidrostatik, perhitungan fisis penampang suhu cakram pasif dan agihan energy spektral. Setiap bagian cakram memancarkan radiasi benda hitam pada suhu lokal.

Model pengembangan cakram sepanjang $r$ merupakan konsekuensi penangkapan dan proses ulang fraksi fluks bintang yang lebih besar. Menurut Kenyon dan Hartmann dalam Armitage, P. (2007), pada radii yang besar model pengembangan cakram mendekati penampang suhu $T \propto r^{-1 / 2}$. Cakram menyerap radiasi bintang yang dekat dengan lapisan permukaan cakram. Lapisan permukaan debu panas meradiasi ulang setengah fluks bintang. Bagian dalam cakram memproses ulang setengah fluks bintang lain dan memancarkannya kembali sebagai radiasi termal.

Mekanisme yang menyebabkan pembubaran cakram diberikan oleh pengamatan HST bintang bermassa rendah. Pengamatan ini menyingkap fluks magnetik yang dihasilkan bintang masif di dalam inti cluster trapezium Nebula Orion (O'Dell, Wen dan Hu dalam Armitage, P., 2007). Gambar yang didapatkan nampak adanya bentuk kecebong nebulae disekitar bintang muda dengan cakram circumstellar yang diinterpretasikan sebagai tanda fotoevaporasi dan meninggalkan cakram gas sebagai hasil iluminasi oleh radiasi ionisasi eksternal. Radius kritis paling luar, $r_{g}$ diberikan dengan persamaan :

$$
r_{g}=\frac{G M}{c_{s}^{2}}
$$

Kecepatan suara dalam gas panas melampaui kecepatan Keplerian lokal. Gas kemudian tidak berikatan dan mengalir keluar dari cakram sebagai angin termal.

Bintang-bintang bermassa rendah kebanyakan menerima dosis radiasi ultraviolet terlalu rendah dari sumber eksternal untuk merusak cakram mereka. 
Proses lain yang membuat bubarnya cakram adalah fotoevaporasi yang menyebabkan radiasi dari pusat bintang. Laju massa yang hilang karena fotoevaporasi dinyatakan dalam persamaan:

$\dot{M}_{\text {wind }} ; 4 \times 10^{-10}\left(\frac{\Phi}{10^{41} s^{-1}}\right)^{1 / 2}\left(\frac{M_{*}}{M_{\mathrm{e}}}\right)^{1 / 2} M_{\mathrm{e}} y r^{-1}$

dengan $\Phi$ merupakan fluks ionisasi bintang.

Gas yang membentuk protoplanet berisi butiran debu interstellar yang terbuat dari campuran Silikat, Grafit dan Polisiklik Aromatik Hidrokarbon (PAH). Pada ISM pengukuran panjang gelombang dapat dilakukan dengan asumsi butiran debu mengikuti distribusi hukum daya (Mathis, Rumpl dan Nordsieck dalam Armitage, P., 2007) sebagai berikut

$$
n(a) \propto a^{-3,5}
$$

dengan $a$ adalah ukuran butiran yang diasumsikan berbentuk bola dan distribusi berkisar antara 0,005-1 $\mu \mathrm{m}$. Agihan ini diasumsikan secara umum sebagai titik awal evolusi dalam kondisi yang lebih rapat. Pada keadaan paling panas, suhu bagian dalam cakram dapat tercapai sehingga merusak butiran.

Jika gas yang membentuk cakram protoplanet memiliki komposisi unsur yang telah diketahui, maka para ahli kimia dapat menghitung tekanan dan suhu kimiawi secara termodinamika. Kelimpahan beragam mineral dan es dalam cakram akan mengikuti tahap kondensasi ini yang membutuhkan waktu untuk melakukan reaksi kimia sampai tercapai keadaan kesetimbangan. Kesetimbangan campuran lebih bergantung pada suhu daripada tekanan sehingga tahap kondensasi dapat dibuat dengan predikasi variasi komposisi cakram terhadap radius.

Matahari terbentuk dari material yang berputar pada bidang equator di sepanjang inti Nebula dan kemudian mengalir membentuk benda simetri bola. Pada protomatahari Nebula terjadi proses fisis yang mengakibatkan proses kimiawi.

Sinar $\mathrm{X}$ dan ultraviolet diduga berasal dari pusat bintang karena bintang sangat aktif waktu masih muda, dengan latar belakang sinar kosmik yang berasal dari sinar kosmik galaktik, ultraviolet interstellar dan dekat dengan bintang masif yang dapat membuat fotoevaporasi cakram atau memanaskan cakram. Proses pencampuran terjadi karena cakram berturbulensi.

Turbulensi mengangkut material dalam arah vertikal dan radial. Pembentukan planet dari partikel debu berukuran submikron memerlukan pertumbuhan sedikitnya dengan orde magnitudo 12 dalam skala ruang.

Pembentukan planet terjadi dalam tiga tahap, yaitu: (i) dari debu menjadi planetesimal, (ii) dari planetesimal menjadi embrio planet, dan (iii) dari embrio planet menjadi planet. Pertumbuhan planetesimal yang saling bertumbukan akan menghasilkan planetplanet terrestrial. Pertumbuhan inti planetesimal akan menghasilkan planetplanet gas raksasa.

Pada proses awal pembentukan, terjadi tumbukan yang tidak terkendali. Salah satunya adalah tumbukan planet dengan komet. Komet yang mengandung es akan memberikan air pada planet yang ditumbuknya. Planet yang dapat menyimpan air dalam bentuk cairan adalah Bumi, sehingga Bumi menjadi satusatunya planet yang berada dalam wilayah habitable.

Pembentukan satelit merupakan bagian kecil dari proses pembentukan planet. Satelit terbentuk dalam cakram debu yang mengelilingi runtuhnya protoplanet.

Asteroid merupakan hasil dari usikan sebuah planet. Asteroid terbentuk dari pengumpulan benda-benda kecil yang tersusun pada saat pertumbuhan 
planetesimal dalam sebuah Nebula Matahari. Pembentukan benda-benda ini didominasi oleh unsur Besi, batu atau material sejenis Karbon Chondrite. Pembentukan meteorit merupakan hasil usikan Asteroid.

$\begin{array}{rrr}\text { Hasil pengamatan } & \text { spektroskopi } \\ \text { menunjukkan } & \text { bahwa } & \text { meteorit }\end{array}$
berhubungan dengan Asteroid. Meteorit merupakan pecahan dari Asteroid. Meteorit memberikan informasi tentang asal mula terbentuknya tata surya. Meteorit merupakan sampel dari bagian material padat dan cair yang dimiliki sebuah planet.

Komet berasal dari material yang tetap ada saat terjadi pembentukan planet pada awal pembentukan tata surya, tetapi material ini tidak bergabung membentuk planet, melainkan berkembang dengan syarat batas tertentu menjadi Komet.

Pendapat lain menyatakan Komet berasal dari hasil usikan benda-benda yang lebih besar sebagai induk dari Asteroid. Pembentukan komet berhubungan dengan Asteroid. Pendapat lain lagi menyatakan bahwa Komet berasal dari usikan awan molekuler raksasa. Hasil usikan tersebut menghasilkan awan molekuler raksasa baru yang kemudian disebut awan Oort. Sebuah Komet terbentuk bersamaan dengan proses terbentuknya awan Oort.

Setelah planet-planet terbentuk, ada sejumlah planetesimal yang tersisa. Kebanyakan orbit planetesimal tersebut tidak stabil, sehingga cepat atau lambat salah satu dari mereka ada yang bergerak mendekati planet. Ketika sudah berada dekat dengan sebuah planet, orbitnya diubah oleh medan gravitasi planet, sehingga akan terjadi dua kemungkinan keadaan.

Keadaan pertama, planetesimal akan masuk menumbuk planet. Tumbukan planetesimal dengan planet dapat menyebabkan sumbu rotasi dan kecepatan planet berubah. Peristiwa ini dapat menjelaskan kenapa Venus dan Uranus memiliki arah putaran yang berbeda dengan planet-planet yang lain.

Keadaan kedua, planetesimal akan terlempar keluar, bahkan bisa saja terlempar keluar dari tata surya. Supaya hukum kelestarian energi berlaku, planet tersebut harus pindah ke posisi yang lebih rendah pada medan gravitasi Matahari. Perubahan posisi ini sangat kecil, tetapi setelah beberapa milyar tahun kemudian, akan terlihat perubahan posisi yang cukup signifikan dari posisi awalnya. Perubahan posisi planet ini kemudian dikenal dengan istilah migrasi planet.

Migrasi planet dapat menjadi permasalahan yang sangat kompleks ketika melibatkan planet-planet raksasa. Model ini dapat memberikan gambaran perubahan posisi planet raksasa seperti Jupiter, berpindah posisi mendekati Matahari.

\section{SIMPULAN DAN SARAN \\ Simpulan}

1. Asal usul terbentuknya tata surya dan sistem keplanetan berawal dari gagasan Laplace yang menyatakan bahwa berawal dari suatu putaran awan gas akan terjadi empat mekanisme berikut:

a. Orbit semua planet-planet berada pada satu bidang yang sama.

b. Semua planet mengelilingi Matahari dalam arah yang sama.

c. Lintasan orbit planet hampir semuanya berupa lingkaran.

d. Putaran planet pada sumbunya sama dengan arah orbitnya pada Matahari.

2. Berdasarkan hasil pengamatan dan studi teoritis beberapa peneliti dan ilmuwan pada bidang Astrofisika dan Astronomi, tata surya dan sistem keplanetan terbentuk dari sebuah bintang. Berawal dari proses kelahiran bintang, hingga terbentuknya cakram bintang, tata surya dan sistem keplanetan berkembang dengan kesetimbangan internal dan syarat batas tertentu. 


\section{Saran}

1. Penelitian ini membahas masalah pembentukan dan evolusi awal tata surya secara teoritis yang dikaitkan dengan hasil pengamatan. Penurunan matematis dilakukan dengan menggunakan pendekatan yang sederhana sehingga masih banyak parameter yang dianggap ideal. Padahal di alam semesta masih terdapat bendabenda dengan sistem yang memiliki parameter tidak ideal. Hal ini membuka penelitian lebih lanjut.

2. Pembentukan tata surya dan sistem keplanetan mencakup pembentukan semua benda-benda yang berada di dalamnya, sehingga mencakup wilayah yang sangat luas sekali. Penelitian ini hanya membahas sistem pembentukan planet-planet secara terperinci tetapi tidak untuk pembentukan benda-benda luar angkasa lain. Hal ini membuka peluang penelitian lebih lanjut.

\section{DAFTAR PUSTAKA}

Admiranto, A. G. (2009). Menjelajahi Bintang, Galaksi dan Alam Semesta, Edisi Kedua, Penerbit Kanisius, Yogyakarta.

Alles, D. A. (2006). The Formation of Star and Solar System, ales@biol.wwu.edu, This web paper was last update 10/13/06.

Anonim. (2008). Universe, Encyclopedia Britannica, Inc., Chicago.

Arfken, G. B. dan Weber, H. J. (2005) Mathematical Method for Physicist, Sixth Edition, Elsevier Inc., Burlington, USA.

Armitage, P. (2007) Lecture Notes on the Formation and Early Evolution of Planetary systems, ArXvi: astrophy/0701485v1: $1-51$.

Boas, M. L. (1983) Mathematical Methode in the Physical Sciences, John \& Willey Sons, New York, USA.
Boss, A. P., From Molekular Clouds to Circumstellar Disks, Comet II: 67 80, Diakses pada 30 Mei 2009.

Cassen, P. (2006) Protostellar Disks and Planet Formation, In Mayor M, Quelos D, Udry S and Benz W (eds) Extrasolar Planets Saas - Fce Adv courses vol. 31: $369-448$.

Dullemond, C. P. dkk. (2006). Models of Structure and Evolution of Planetary disks, ArXvi: astro-phy/0602619v1: $1-18$.

Eales, S. (2009). Planet and Planetary Systems, First Edition, John Wiley \& Sons, Ltd, Singapore.

Goldreich dan Tremain. (1980). Ap.J, 241, 425.

Karttunen, H., Kröger, P., Oja, H., Pautanen, M., Donner, K. J. (2007) Fundamental Astronomy, Fifth Edition, Springer Berlin Heidelberg, New York.

Kenyon, S. J. (2000) Dynamical Evolution of Protoplanetary Disks, ArXiv: astrophy/0010036v1: 1 - 24.

Levinson dkk. (2007) Protostar and Planet V, eds B., Reiporth, D. Jewitt, and K. Keil, University of Arizona Press, Tucson.

Lin, Bodenheimer, dan Richardson. (1996) Nature, 380,606.

Lin dan Ida. (1997). Ap. J, 477, 781.

Nurrahmi, L. A. (2008). Tinjauan Analitik Teori Migrasi Planet, Skripsi. Program Studi Astronomi, ITB, Bandung, http://digilib.itb.ac.id, diakses 15 februari 2010.

Mizuno, H. (1980). Progress of Theoritical Physics, 64, 544. Pezzaglia, B., 2006, Stellar Evolution, Astrophysics.

Rasio dan Ford. (1996) Science, 744, 954.

Safronov, V. S. (1969) Evolution of the Planetary Cloud and Formation of the Earth and the Planet, English translation NASA TT F-677.

Schilling, G. (1999) From a Swirl of Gas, a Plant is Born, Science: 286. 
Siregar, S. (2001). Mekanika Benda Langit, Penerbit ITB, Bandung. Siregar, S., 2007, Benda Kecil dalam Tata Surya, Penerbit ITB, Bandung.

Umberger, J., Protoplanetary Disks and the First Stage of Planet Formation. 376 Notes Disks Gas Prelim 3.18, Diakses pada 30 Mei 2009.

Weidenchilling dan Marzari. (1996). Nature, $384,619$.

Woolfson, M. M. (2000). The Origin and Evolution of the Solar System, Institute of Physics Publishing Ltd. Bristol and Philadelphia.

Yasrina, A. (2010). Nukleosintesis dan Evolusi Bintang, Skripsi, Program Studi Fisika, FMIPA, UGM, Yogyakarta. 